Thorax (1969), 24, 69.

\title{
Treatment of recurrent malignant pleural effusion by iodized talc pleurodesis ${ }^{1}$
}

\author{
GL Y N NE R. JONES \\ From Sully Hospital (Thoracic Centre), Penarth, Glamorgan
}

\begin{abstract}
Chemical pleurodesis using iodized talc is an effective method of treating symptomatic recurrent malignant pleural effusions. Twenty-three effusions occurring in 21 patients treated by this method are described with two illustrative case reports. The procedure eliminated the need for further chest aspiration in all but one instance. The histological appearances of the pleura at intervals after pleurodesis are also described.
\end{abstract}

The management of recurrent malignant pleural effusions is a difficult problem. Often symptoms are caused by the presence of fluid which reaccumulates rapidly after simple aspiration, rather than by invasive growth affecting the pleura and chest wall. The dyspnoea and troublesome cough from which these patients suffer can be alleviated by the satisfactory suppression of pleural fluid formation. The mechanisms involved in the production of malignant pleural effusions and their symptomatology have been discussed previously (Chambers, 1958 ; Haupt, Camishion, Templeton and Gibbon, 1960 ; Pearson and MacGregor, 1966). A method of palliative treatment which prevents the re-accumulation of pleural fluid would alleviate cough and dyspnoea as well as eliminating the need for repeated chest aspirations.

During the last three decades, several approaches to this problem have been described in the literature. Radiotherapy met with only limited success. Recently, there have been reports of patients treated with intrapleural nitrogen mustard (Mark, Goldenberg, and Montague, 1964), radioactive colloidal gold (Botsford, 1964), and quinacrine hydrochloride (Rochlin, Smart, Wagner, and Silva, 1964 ; Dollinger, Krakoff, and Karnofsky, 1967). Pleurectomy (Jensik, Cagle, Milloy, Perlia, Taylor, Kofman, and Beattie, 1963) and partial decortication with talc (Starkey, 1964) are superior to the chemical methods, whose success rate is variously reported as $50-70 \%$, but they have the disadvantage of a formal thoracotomy.

1 Based on a paper read to the Thoracic Society on March 3, 1967
Talc was first introduced into the human pleural cavity as a sclerosing agent by Bethune in 1935. Talc poudrage is now an accepted form of treatment for spontaneous pneumothorax and has also been used in pericardial effusions and chylothorax. In the palliative treatment of malignant pleural effusions its use was described by Chambers (1958) and it was insufflated into the pleural cavity under local anaesthesia. A similar series was reported in 1960 (Haupt et al.), and the same workers published further cases in 1962 (Camishion, Gibbon, and Nealon, 1962) using a limited thoracotomy to insert the talc. Roche, Delanoe, and Moayer (1963) insufflated talc under general anaesthesia, while Pearson and MacGregor (1966) selected their cases for the local anaesthetic technique or thoracotomy.

This paper describes a series of patients with recurrent malignant pleural effusions who have been treated with iodized talc, introduced by thoracoscopy under general anaesthesia, to create a pleurodesis.

\section{METHOD}

The patient is given a general anaesthetic in the operating theatre. The site of the pleural effusion is accurately located by needle exploration, and a small incision $2 \mathrm{~cm}$. long is made over this point (usually the sixth or seventh intercostal space in the midaxillary line). A non-absorbable suture is inserted into the skin at this stage, which serves to close the incision when the drainage tube (vide infra) is finally removed.

The trocar and cannula (a large Nelson's empyema trocar) are introduced into the pleural space through the incision, and the fluid is drained completely. 
Thoracoscopy is carried out and pleural biopsy can be performed if necessary.

Iodized talc ${ }^{2}$ is then insufflated over as much of the pleural surface as possible, using an 'R.A.F. Pattern' insufflator. The dose used is $5 \mathrm{~g}$. Ventilation of the patient is stopped during the insufflation.

A thick rubber tube ${ }^{3}$ is inserted through the cannula, its thick wall and wide bore making collapse and blockage unlikely. A short length $(0.5 \mathrm{~cm}$.) of the tube is cut off and advanced over the positioned tube up to the incision. A second stitch from this rubber ring to the skin fixes the tube and enables it to be shortened accurately.

The drainage tube is attached to an underwater seal, but no suction is used for 3 hours, thus minimizing the loss of iodized talc by this route. Later, gentle suction $(5 \mathrm{~cm}$. of water) is applied. The withdrawal of the tube is controlled by serial radiographs. Generally, it is possible to remove the tube after three or four days, and the patient is kept in the post-operative ward until this has been done. Opiates are necessary in the early post-operative stages to relieve the pain produced by the irritation of the iodized talc.

\section{MATERIAL}

During the period 1960 to 1966,21 patients were treated in this way for recurrent malignant pleural effusions at Sully Hospital.

Their ages ranged from 19 to 80 years, 16 of them being in the age group 40-65 years. The primary diagnoses are shown in Table I. Fourteen patients had

2 See Appendix, p. 72

3 Messrs Franklins 620B Mix, 34 French gauge carcinoma of the lung. The others had primary growths in the breast, ovary, uterus, stomach, and 0 pancreas. There was one case of lymphosarcoma and $\bar{\sigma}$ one of osteosarcoma-both in young adults. Twenty- $\overline{\bar{C}}$ three effusions were treated in these 21 patients, as $\overrightarrow{\mathbb{D}}$ two had bilateral effusions when both sides were $\varrho$ treated on separate occasions. (For simplicity, the $\infty$ progress of each side is followed separately.)

The interval batween successive chest aspirations in these patients varied from two days to two months. $\vec{\omega}$ Most required aspiration two or three times a week in hospital prior to pleurodesis.

All patients were followed up to the time of death, and necropsies were performed in seven of them + (Table I).

\section{RESULTS}

The total number of chest aspirations necessary $\vec{c}$ in these 21 patients before pleurodesis was 102 . Following the procedure only one patient needed aspiration (case 3)-on one occasion.

In Table II the chest radiological appearances before pleurodesis have been compared with the most recent films available. In five patients the appearances were unchanged, and in one instance the effusion was larger; but their symptoms had been relieved. In 13 patients the effusion was smaller, while in the remaining three, the lung had either fully expanded or there was a small amount of fluid in the costophrenic angle.

The survival time of these 21 patients from the date of pleurodesis to death is shown graphically in the Figure. (As stated above, bilateral effusions are followed separately.)

T A B L E I

GENERAL DATA

\begin{tabular}{|c|c|c|c|c|c|}
\hline $\begin{array}{l}\text { Case } \\
\text { No. }\end{array}$ & Sex & $\underset{\text { (years) }}{\text { Age }}$ & Diagnosis & $\begin{array}{c}\text { Survival } \\
\text { after Talc }\end{array}$ & Other Treatment and Remarks \\
\hline $\begin{array}{r}1 \\
2 \\
3 \\
4 \\
5 \\
6 \\
7 \\
8 \\
9 \\
10 \\
11 \\
12 \\
13 \\
14 \\
15 \\
16 \\
17 \\
18 \\
19 \\
20 \\
21\end{array}$ & $\begin{array}{l}\mathbf{M} \\
\mathbf{F} \\
\mathbf{M} \\
\mathbf{M} \\
\mathbf{M} \\
\mathbf{F} \\
\mathbf{F} \\
\mathbf{M} \\
\mathbf{M} \\
\mathbf{F} \\
\mathbf{M} \\
\mathbf{M} \\
\mathbf{F} \\
\mathbf{M} \\
\mathbf{M} \\
\mathbf{M} \\
\mathbf{F} \\
\mathbf{F} \\
\mathbf{M} \\
\mathbf{F}\end{array}$ & $\begin{array}{l}58 \\
64 \\
58 \\
61 \\
62 \\
57 \\
75 \\
51 \\
65 \\
70 \\
19 \\
43 \\
43 \\
60 \\
64 \\
43 \\
19 \\
56 \\
53 \\
80 \\
62\end{array}$ & $\begin{array}{l}\text { Carcinoma lung } \\
\text { Carcinoma breast } \\
\text { Carcinoma stomach } \\
\text { Carcinoma lung } \\
\text { Carcinoma lung } \\
\text { Carcinoma lung } \\
\text { Carcinoma lung } \\
\text { Carcinoma ovary } \\
\text { Carcinoma lung } \\
\text { Carcinoma lung } \\
\text { Lymphosarcoma } \\
\text { Carcinoma lung } \\
\text { Carcinoma lung } \\
\text { Carcinoma lung } \\
\text { Carcinoma lung } \\
\text { Carcinoma pancreas } \\
\text { Osteosarcoma } \\
\text { Carcinoma lung } \\
\text { Carcinoma uterus } \\
\text { Carcinoma lung } \\
\text { Carcinoma lung }\end{array}$ & $\begin{array}{l}6 \text { months } \\
17 \text { months } \\
4 \text { months } \\
11 \text { months } \\
16 \text { months } \\
6 \text { months } \\
15 \text { months } \\
12 \text { months } \\
29 \text { months } \\
2 \text { weeks } \\
7 \text { months } \\
6 \text { months } \\
12 \text { weeks } \\
2 \text { weeks } \\
3 \text { months } \\
4 \text { months } \\
1 \text { month } \\
6 \text { weeks } \\
1 \text { month } \\
3 \text { weeks } \\
1 \text { month } \\
1 \text { day } \\
7 \text { months }\end{array}$ & $\begin{array}{l}\text { (Right) Bilateral effusions } \\
\text { (Left) } \\
\text { Thiotepa, cyclophosphamide, deep } x \text { rays } \\
\text { Necropsy } \\
\text { (Left) Bilateral effusions, chlorambucil } \\
\text { (Right) Nitrogen mustard, vinblastine. Necropsy } \\
\text { Died of melaena. Necropsy } \\
\text { Cyclophosphamide } \\
\text { Nitrogen mustard, deep } x \text { rays } \\
\text { Nitrogen mustard, cyclophosphamide } \\
\text { Blocked main bronchus. Necropsy } \\
\text { Nitrogen mustard, deep } x \text { rays } \\
\text { Necropsy } \\
\text { Necropsy. No post-operative } x \text { rays }\end{array}$ \\
\hline
\end{tabular}


T A B L E I I

CHEST RADIOGRAPH APPEARANCES BEFORE AND AFTER PLEURODESIS

\begin{tabular}{|c|c|}
\hline $\begin{array}{l}\text { Most Recent Chest Radiograph } \\
\text { Appearances compared to } \\
\text { Pre-pleurodesis }\end{array}$ & Case Nos. \\
\hline Worse & 17 \\
\hline Similar & $2,3,9,11,13$ \\
\hline Smaller pleural effusion & $\begin{array}{l}1,4,6,7,10,11,12 \\
14,15,16,18,19\end{array}$ \\
\hline $\begin{array}{l}\text { Fully expanded, or small amount } \\
\text { of fluid in costophrenic angle }\end{array}$ & $5,8,21$ \\
\hline
\end{tabular}

\section{CASE REPORTS}

CASE 11 A girl aged 19 years was admitted on 20 May 1965 with a three-month history of progressive dyspnoea, malaise, and weight loss. A clinical diagnosis of reticulosis was confirmed by lymph node biopsy, which showed lymphosarcoma.

The chest radiograph, taken on admission, revealed bilateral pleural effusions. In view of the extensive nature of the disease, she was treated with oral chlorambucil. During the next seven weeks, 14 pleural aspirations were necessary ( 9 on the left side and 5 on the right). She also developed bone marrow depression.

Iodized talc pleurodesis was performed in the left pleural cavity on 8 July 1965, and no further aspirations were necessary on this side. Nitrogen mustard (20 mg.) was infused intravenously and she was discharged in August 1965.

On 14 October 1965 she was re-admitted with dyspnoea, purpura, and oedema, and had deteriorated generally. Oral prednisone followed by vinblastine failed to control the right-sided pleural effusion, which was aspirated on five occasions during the next 10 weeks. Her chest radiograph of 22 December 1965 showed some fluid in the left pleural cavity, but the appearances had not altered during the previous five months.

Iodized talc poudrage was performed on the right side on 7 January 1966. No further chest aspirations were necessary before she died on 19 January 1966.

CASE 8 A woman aged 50 years presented in July 1964 with a large right-sided pleural effusion. A pleural biopsy was suggestive of a poorly differentiated neoplasm, and malignant cells were also seen in the pleural fluid. The primary growth was not discovered at this stage. Pleural aspirations were necessary twice a week. She was treated with intrapleural thiotepa, which reduced the frequency of her aspirations to once a month.

Four months later the effusion again re-accumulated rapidly. After a total of 10 pleural aspirations, iodized talc poudrage was performed in November 1964.
In February 1965 she developed ascites and was found to have a pelvic mass. Laparotomy revealed an inoperable papillary adenocarcinoma of the ovary. Repeated abdominal paracenteses were necessary for ascites, but no further pleural aspirations were performed before she died in April 1967. The last available chest radiograph was taken 14 months after pleurodesis and did not show any pleural effusion.

\section{COMMENT AND DISCUSSION}

The mechanisms involved in the production of malignant pleural effusions vary from case to case, and in different primary growths. Pleural seeding, lymphatic obstruction, venous obstruction, hypoproteinaemia, pneumonia, and inflammatory exudation are of importance in the pathogenesis. The method of treatment which is most likely to be effective in all the above is one which produces fibrous union between the affected pleural surfaces, with obliteration of the pleural cavity, i.e., pleurodesis.

Talc was found to be the best agent for producing pleurodesis by Singer, Jones, and Tragermann (1941). This was confirmed by Frankel, Krasna, and Baronofsky (1961), who said that talc produced satisfactory pleural symphysis but that other chemical agents were uncertain in their ability to do this and were frequently useless. The iodine added to the talc serves to keep the talc sterile and itself produces an inflammatory reaction.

Iodized talc pleurodesis has been used at Sully Hospital for many years in the treatment of spontaneous pneumothorax (Smith and Rothwell, 1962) and chylothorax (Gingell, 1965). Its administration does not require expensive apparatus nor does it affect the haemopoetic system, as may occur with radioisotopes or alkylating agents. Talc poudrage has not the disadvantages of radiotherapy, namely, general morbidity, prolonged hospitalization, and possibly pulmonary fibrosis later. However, the introduction of iodized talc into the pleura is painful, and it is for this reason that the procedure is carried out under general anaesthesia. Analgesics are usually necessary post-operatively.

Seven patients in this series received antimalignant drug therapy (five by the intrapleural route), and three of these had local radiotherapy (Table I) before pleurodesis was carried out. Neither of these treatments made any difference to the recurrence rate of the pleural effusion before pleurodesis.

The survival time of the patients (Figure) shows that half of them lived for only four months or 


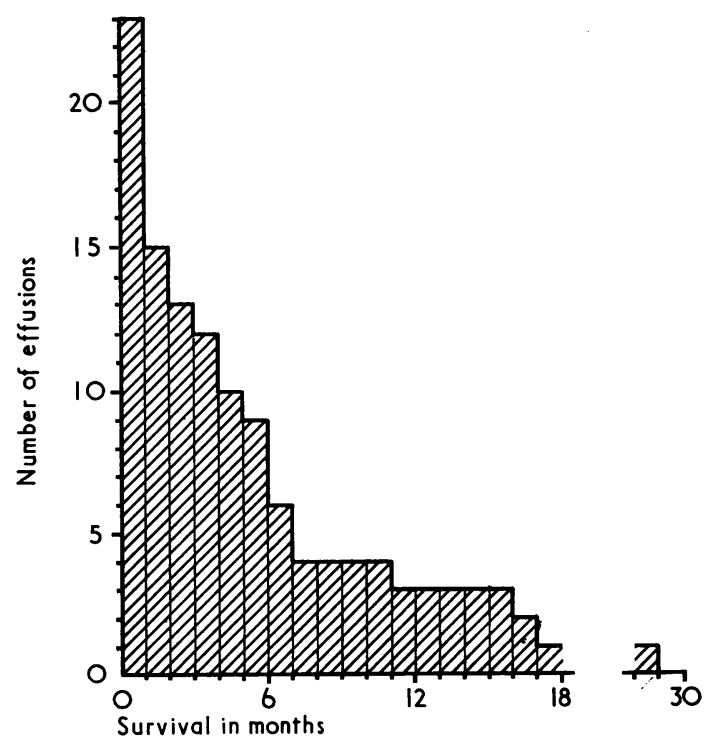

FIGURE. Progress of 23 effusions (in 21 patients) from date of pleurodesis to death.

less. However, a few survived longer, without the need for further chest aspiration, following pleurodesis.

Necropsies were performed on seven patients (Table I), enabling the effect of the iodized talc to be studied at intervals after pleurodesis. During the first two weeks the pleura was covered with a haemorrhagic fibrinopurulent exudate. By the third week, the response was more collagenous, with areas of necrosis, and talc granulomata were present. At 6 months there was much dense pleural fibrosis. Sparse talc particles were seen under polarized light. At 17 months, case 2 showed areas of old talc sclerosis, invaded and surrounded by tumour cells (a poorly differentiated carcinoma of the breast).

There is no evidence that iodized talc has any influence on the growth of the tumour. Even antimalignant agents, when introduced into the pleural cavity, are thought to produce their effect by causing an inflammatory reaction resulting in pleurodesis, rather than by a direct action on the neoplastic cells (Chambers, 1958; Pearson and MacGregor, 1966). Iodized talc appears more effective for this purpose. Its action is probably purely mechanical in preventing the re-accumulation of pleural fluid and intrapleural spread of the tumour.

There are few contra-indications to talc poudrage. Pleurodesis may fail in the presence of complete obstruction of a main bronchus $\stackrel{\vec{F}}{\stackrel{\vec{f}}{+}}$ preventing full lung expansion. Such a lesion was? present in case 16. Necropsy six weeks after poud-ㅡㅡㅁ rage showed a persistent pleural space. The necrotic fibrinopurulent exudative reaction hado occurred, but superficially in the pleural cavityen there was a zone of proliferating branching fungat mycelium, resembling Aspergillus. Other possiblereasons for the failure of pleurodesis are pleuratw rigidity and the presence of a broncho-pleura? fistula.

\section{CONCLUSION}

The pessimism with which malignant pleurab effusions were formerly regarded has been replaced by a degree of optimism with the realization that the ultimate prognosis in the individual patient depends largely upon the naturen and extent of the primary growth and on the methods of specific treatment available. Thus $\overrightarrow{0}$ carcinoma of the breast has a better prognosise than carcinoma of the lung, with or without ad pleural effusion. A palliative method of treatmenf which prevents the re-accumulation of pleurap fluid and eliminates the need for further chesw aspirations is of symptomatic and psychologicafo benefit to the patient. The use of iodized talc as described above is effective for this purpose.

\section{APPENDIX}

METHOD OF PREPARATION OF IODIZED TALC Five grammes of light kaolin are dried, sifted, and placed in a universal container, fitted with a silii:con rubber insert, for 2 hours at $160^{\circ} \mathrm{C}$. Iodine 3 . $100 \mathrm{mg}$., is dissolved in $4 \mathrm{ml}$. anaesthetic ether and $1 \mathrm{ml}$. of this solution is added to the kaolin after sterilization. Each dose of kaolin containso $0.025 \mathrm{~g}$. iodine. This iodized talc is freshly pre pared, and is used within 24 hours.

I wish to thank the physicians and surgeons of Sully Hospital for allowing me to review thesw patients. The cases described in detail were under the care of Dr. G. S. Kilpatrick and Dr. L. R. West respectively. Dr. West gave invaluable assistance witle the preparation of the Figure. Finally, I express mye gratitude to Miss J. R. Barry, who typed the manū script, and to Dr. H. M. Foreman and Dr. R. M. Seaff for advice and encouragement.

\section{REFERENCES}

Bethune, N. (1935). J. thorac. Surg., 4, 251.

Botsford, T. W. (1964). Experiences with radioactive colloidal golo in the treatment of pleural effusion caused by metastatic cance of the breast. New Engl. J. Med., 270, 552 . 
Camishion, R. C., Gibbon, J. H., and Nealon, T. F. (1962). Talc poudrage in the treatment of pleural effusion due to cancer. Surg. Clin. N. Amer., 42, 1521.

Chambers, J. S. (1958). Palliative treatment of neoplastic pleural effusion with intercostal intubation and talc instillation. West.J. Surg., 66, 26.

Dollinger, M. R., Krakoff, I. H. and Karnofsky, D. A. (1967). Quinacrine (Atabrine) in the treatment of neoplastic effusions. Ann. intern. Med., 66, 249.

Frankel, A., Krasna, I. and Baronofsky, I. D. (1961). An experimenta study of pleural symphysis. J. thorac. cardiovasc. Surg., 42, 43.

Gingell, J. C. (1965). Treatment of chylothorax by producing pleurodesis using iodized talc. Thorax, 20, 261.

Haupt, G. J., Camishion, R. C., Templeton, J. Y., and Gibbon, J. H. (1960). Treatment of malignant pleural effusions by talc poudrage. J. Amer. med. Ass., 172, 918.

Jensik, R., Cagle, J. E., Milloy, F., Perlia, C., Taylor, S., Kofman, S. and Beattie, E. J. (1963). Pleurectomy in the treatment of pleural effusion due to metastatic malignancy. $J$. thorac. cardiovasc. Surg., 46, 322.
Mark, J. B. D., Goldenberg, I. S., and Montague, A. C. (1964). Intrapleural mechloroethamine hydrochloride therapy for malignant pleural effusion. J. Amer. med. Ass., 187, 858.

Pearson, F. G., and MacGregor, D. C. (1966). Talc poudrage for malignant pleural effusion. J. thorac. cardiovasc. Surg., 51, 732.

Roche, G., Delanoe, Y., and Moayer, N. (1963). Talcage de la plèvre sous pleuroscopie. Résultats, indications, technique. J. franç. méd. Chir. thorac., 17, 677.

Rochlin, D. B., Smart, C. R., Wagner, D. E., and Silva, A. R. M. (1964). The control of recurrent malignant effusions using quinacrine hydrochloride. Surg. Gynec. Obstet., 118, 991.

Singer, J. J., Jones, J. C. and Tragermann, L. J. (1941). Aseptic pleuritis experimentally produced. $J$. thorac. Surg., 10, 251; quoted in Pleural Reactions to Irritants (1965) by Thorsrud, G. K., Acta chir. scand., Suppl. 355.

Smith, W. G., and Rothwell, P. P. G. (1962). Treatment of spontaneous pneumothorax. Thorax, 17, 342.

Starkey, G. W. B. (1964). Recurrent malignant pleural effusions. New Engl. J. Med., 270, 436. 